\title{
EKONOMSKI GUBITCI KAO ŠTETA U HRVATSKOM ODŠTETNOM PRAVU NAKON PRENOŠENJA DIREKTIVE 2014/104/EU
}

Dr. sc. Maja Bukovac Puvača, izvanredna profesorica Pravni fakultet Sveučilišta u Rijeci
UDK: 347.5.05::061.1EU

Ur.: 30. siječnja 2017.

Pr.: 7. veljače 2017.

Pregledni znanstveni rad

\section{Sažetak}

Krajem 2014. godine usvojena je Direktiva 2014/104/EU koja bi trebala olakšati ostvarivanje prava na naknadu štete subjektima koji štetu pretrpe zbog povreda prava tržišnog natjecanja. U radu se upozorava na neka od spornih pitanja o odgovornosti za štetu koja su pri njenom donošenju prepoznata kao takva, ali ih europski zakonodavac nije uspio usuglasiti. Rad se detaljnije bavi samim pojmom štete, odnosno gubitcima za koje Direktiva od država članica očekuje da u postupcima za naknadu štete pred svojim sudovima osiguraju učinkovito ostvarivanje prava na njihovu naknadu. Zbog same prirode štetnih radnji kojima se narušava tržišna utakmica (zabranjenih sporazuma $i$ zlouporabe vladajućeg položaja), upozorava se da bi provođenje usvojenih rješenja u praksi moglo biti vrlo komplicirano. Posebno se ističu problemi prigovora prenošenja prekomjernih cijena, priznavanja pravnog interesa neizravnim kupcima, priznavanja učinka zaštitne cijene te izračunavanja iznosa naknade štete koju bi oštećenicima trebalo dosuditi. U radu se prikazuju odredbe nacrta prijedloga zakona kojim bi Direktiva trebala biti prenesena u naše zakonodavstvo, a koje se odnose na u radu obrađena pitanja.

Ključne riječi: tržišno natjecanje, popravljanje štete, imovinska šteta, neimovinska šteta.

\section{1. $U V O D$}

Direktiva 2014/104/EU Europskog parlamenta i Vijeća od 26. studenoga 2014. godine o određenim pravilima kojima se uređuju postupci za naknadu štete prema nacionalnom pravu za kršenje odredaba prava tržišnog natjecanja država članica i Europske unije ${ }^{1}$ u nacionalna zakonodavstva trebala je biti prenesena do 27 . prosinca 2016. godine. Tri su osnovna cilja koja se Direktivom nastoje postići: da svatko tko je pretrpio štetu prouzročenu povredom prava tržišnog natjecanja može učinkovito ostvariti pravo na naknadu iste od štetnika, da se u cijeloj Uniji osigura jednakovrijedna

1 Službeni list Europske unije, L 349/1, 5.12.2014., dalje: Direktiva. 
zaštita oštećenika te da se koordiniraju javnopravna i privatnopravna provedba pravila tržišnog natjecanja. ${ }^{2}$ Rad na samoj Direktivi dugo je trajao, oko nekih temeljnih pitanja nije se uspjela postići suglasnost, pa su ili potpuno izostavljena ili su rješenja iz Direktive rezultat kompromisa i kao takva će vjerojatno izazvati teškoće u primjeni. U vrijeme pisanja ovoga rada u tijeku je javno savjetovanje ${ }^{3}$ o nacrtu Prijedloga Zakona o postupcima naknade štete zbog povreda prava tržišnog natjecanja, ${ }^{4}$ koji se donosi u svrhu prenošenja Direktive u naše zakonodavstvo i za koji se predlaže donošenje po hitnom postupku. Iako je Zakonom o zaštiti tržišnog natjecanja ${ }^{5}$ u čl. 69. $a^{6}$ izričito propisana odgovornost poduzetnika za štetu prouzročenu povredom odredaba toga zakona i čl. 101. i 102. Ugovora o funkcioniranju Europske unije (dalje: UFEU),

2 Vidi čl. 1. Direktive. Komisija EU je još 2005. g donijela Zelenu knjigu za naknadu štete zbog povreda pravila tržišnog natjecanja (Green Paper, damages actions for breach of the EC antitrust rules, COM (2005) 672 final, 19.12.2005., dalje: Zelena knjiga) i objavila studiju o naknadi te štete. Zelenom knjigom su kao osnovne prepreke u ostvarivanju prava na naknadu štete istaknuti: ograničena mogućnost postavljanja kolektivnih zahtjeva za naknadu štete, pravila o teretu dokaza krivnje i općih pretpostavki odgovornosti, pravila o prikupljanju i izvođenju dokaza te dokaznoj snazi odluka regulatornih agencija, opseg priznatih šteta i metode utvrđivanja iznosa u kojem su pretrpljene, dopuštenost prigovora prijenosa štete, kratki rokovi zastare, visoki troškovi postupka i pravila o mjerodavnom pravu (Zelena knjiga, str. 12.-14.). U travnju 2008. godine Komisija je objavila Bijelu knjigu (White Paper on Damages Actions for Breach of the EC antitrust rules $\operatorname{COM}(2008)$ 165, 2.4.2008.) i dvije iznimno iscrpne popratne studije koje detaljno obrazlažu očekivane učinke reforme (Commission Staff working paper SEC(2008) 404, 2.4.2008. i Impact Assessment Report SEC(2008) 405, 2.4.2008.)

3 http://www.aztn.hr/pripremljen-zakon-o-postupcima-za-naknade-stete-zbog-povreda-pravatrzisnog-natjecanja/ (27.01.2017.)

4 Nacrt Prijedloga Zakona o postupcima naknade štete zbog povreda prava tržišnog natjecanja. Predlagatelj je Ministarstvo gospodarstva, a tekst prijedloga je od 9. studenog 2016. godine, dalje u tekstu: Prijedlog.

5 Narodne novine 79/09, 80/13, dalje: ZZTN.

6 Članak 69.a:

(1) O naknadama štete zbog povreda ovoga Zakona ili članka 101. ili 102. UFEU odlučuju nadležni trgovački sudovi.

(2) Poduzetnici koji su povrijedili odredbe ovoga Zakona ili članka 101. ili 102. UFEU odgovorni su za naknadu štete nastalu tim povredama.

(3) Nadležni trgovački sud će pri donošenju odluke o naknadi štete iz stavka 1. ovoga članka osobito uzeti u obzir pravomoćno rješenje Agencije kojim je utvrđena povreda ovoga Zakona ili članka 101. ili 102. UFEU, odnosno konačnu odluku Europske komisije u slučaju kada je Europska komisija utvrdila povredu članka 101. ili 102. UFEU. Navedeno ne dovodi u pitanje prava i obveze iz članka 267. UFEU.

(4) Ako je postupak utvrđivanja povrede članka 101. ili 102. UFEU u tijeku pred Agencijom ili Europskom komisijom, nadležni trgovački sud može procijeniti je li svrhovito nastaviti ili zastati s postupkom do donošenja pravomoćnog rješenja Agencije ili konačne odluke Europske komisije.

(5) Nadležni trgovački sud dužan je bez odgađanja obavijestiti Agenciju o podnesenoj tužbi radi utvrđivanja prava na naknadu štete nastale povredom odredbi ovoga Zakona ili članka 101. ili 102. UFEU.

(6) Tijek zastare za podnošenje tužbe radi ostvarivanja prava na naknadu štete iz stavka 1. ovoga članka prekida se od dana pokretanja postupka u nadležnosti Agencije ili Europske komisije do dana okončanja tih postupaka.”. 
dakle, nacionalnog i europskog prava tržišnog natjecanja, oštećenici takve sporove pred našim sudovima uglavnom ne pokreću. ${ }^{7}$ Direktiva bi se trebala primjenjivati samo na slučajeve povrede europskog prava tržišnog natjecanja (čl. 101. i 102. UFEU) i slučajeve povrede nacionalnog prava tržišnog natjecanja kada se ono primjenjuje usporedno s europskim, ${ }^{8}$ odnosno ne bi trebala utjecati na postupke za naknadu štete zbog kršenja nacionalnog prava tržišnog natjecanja koja ne utječu na trgovinu među državama članicama u smislu čl. 101. i 102. UFEU-a. ${ }^{9}$ Međutim, kako je i bilo za očekivati, pri prenošenju Direktive, nacionalni su se zakonodavci (i naš predlagatelj ${ }^{10}$ ) odlučili za jedinstvenu primjenu novih pravila i na postupke za naknadu štete zbog povrede europskog i one zbog povrede nacionalnog prava tržišnog natjecanja. ${ }^{11}$ Do prenošenja Direktive na tu se štetu, odnosno odgovornost za istu, primjenjuju opća pravila o odgovornosti. Hoće li posebna pravila, trenutno u Prijedlogu, a uskoro

7 Izostanak tužbi za naknadu štete prouzročene povredama pravila tržišnog natjecanja nije karakterističan samo za našu državu, već predstavlja jedan od osnovnih motiva za donošenja Direktive. Samo se u tri europske države u nešto većem broju pokreću postupci za naknadu štete: Velikoj Britaniji, Njemačkoj i Nizozemskoj, i to oni postupci koji slijede nakon odluka Komisije ili nacionalnih tijela nadležnih za tržišno natjecanje da je došlo do povrede. Analize nekih karakteristika takvih postupaka (prema njihovom broju, visini upravnih kazni...) vidi kod: Friederiszick, Hans, W., Rauber, Michael, A Fleet Without a Captain? Taking Stock of European Antitrust Litigation Post EU Directive, CPI Antitrust Cronicle, January, 2015 (1), www.competitionpolicyinternational.com (27.01.2017.).

Tražeći odgovor na pitanje zašto oštećenici ne podižu tužbe za naknadu štete, Komisija je 2004. godine pokrenula komparativno istraživanje nacionalnih pretpostavki za ostvarivanje prava na naknadu štete radi povreda pravila nacionalnog i europskog prava tržišnog natjecanja. Rezultati istraživanja sadržani su u Ashurst izvješću (Ashurst Study on the conditions of claims for damages in case of infringement of EC competition rules, Comparative report, 31.08.2004., dostupan na:

http://ec.europa.eu/comm/competition/antitrust/others/actions_for_damages/comparative_ report_clean_en.pdf).

I prije dodavanja čl. 69.a u ZZTN (dodan je Zakonom o izmjenama i dopunama Zakona o zaštiti tržišnog natjecanja iz 2013. godine, Narodne novine, broj 80/13 i na snazi je od 1. srpnja 2013. godine), osnova odgovornosti za te štete u našem se pravu mogla pronaći u općoj zabrani nanošenja štete iz čl. 8. Zakona o obveznim odnosima (Narodne novine, broj 35/05, 41/08, 125/11 i 78/15, dalje: ZOO). Vidi: Bukovac Puvača, Maja, Butorac, Vlatka, Izvanugovorna odgovornost za štetu prouzročenu povredom pravila tržišnog natjecanja, Hrvatska pravna revija, br. 12, 2008., str. 34 .

8 Na temelju čl. 3. st. 1. Uredbe Vijeća (EZ) br. 1/2003. od 16. prosinca 2002. o provedbi pravila o tržišnom natjecanju koja su propisana člancima 81. i 82. Ugovora o osnivanju EZ-a (Službeni list L, 4.1.2003.).

9 Preambula Direktive, recital 10.

10 Vidi čl. 3. t. 1. Prijedloga.

11 Jedinstvenim pristupom sprječava se daljnja fragmentacija odnosnih pravila. Pojednostavljuje se i vođenje postupka kada se tijekom istog zaključi da nije bilo učinka na trgovinu među članicama pa ne dolazi do primjene europskog prava tržišnog natjecanja ili kada se radi o višestrukim povredama kod kojih neke imaju, a neke ne europsku dimenziju. Sprečavaju se i zloupotrebe pozivanja na europsko pravo tržišnog natjecanja kako bi se izazvala ili spriječila primjena pojedinog procesnog pravila. Truli, Emmanuela, Will Its provision Serve Its Goals? Directive 2014/104/EU on Certain Rules Governing Actions for Damages for Competition Law Infringements, Jouranl of European Competition Law \& Practice, 2016., vol. 7., br. 5, str. 301. 
u zakonu, bez obzira u kojem konačnom obliku, zaista potaknuti oštećenike da pretrpljene štete počnu utuživati, tek predstoji da vidjeti. ${ }^{12}$ Nacrt Prijedloga sadrži neka posebna pravila o odgovornosti za štetu prouzročenu povredom pravila tržišnog natjecanja $\mathrm{a}^{13}$ kojima se značajno odstupa od općih pravila našeg odštetnog prava i bit će zanimljivo pratiti u kojem će obliku ista biti konačno prihvaćena i hoće li se i kako primjenjivati u praksi.

Ako uzmemo u obzir činjenicu da o nekim temeljnim pitanjima o odgovornosti pri donošenju Direktive nije postignuta suglasnost i ona njome nisu uređena, jasno je da se mogu očekivati teškoće u primjeni općih pravila nacionalnih sustava, odnosno u njihovu "suživotu" s posebnim pravilima donesenim zbog obveze prenošenja Direktive. Sva nacionalna pravila koja uređuju pravo na naknadu štete prouzročene povredom europskog prava tržišnog natjecanja, uključivo ona koja se odnose na pitanja koja nisu uređena Direktivom, ${ }^{14}$ moraju se pridržavati načela učinkovitosti i jednakovrijednosti. ${ }^{15}$

Potrebno je naglasiti iznimnu složenost nekih pitanja o odgovornosti za štetu koja se Direktivom, odnosno Prijedlogom nastoje, tj. trebala bi biti riješena, prije svega, priznatih gubitaka (štete), pretpostavki i vrsta odgovornosti za iste i zastare tužbenih zahtjeva. Svako od njih zaslužuje detaljnu analizu, a u ovom ćemo se radu zadržati na pojmu priznatih gubitaka (štete) koji su posljedica povreda prava tržišnog natjecanja i čije učinkovito popravljanje države članice moraju osigurati pred svojim sudovima. Iako se Prijedlogom po pitanju pojma štete na prvi pogled u našem pravu ništa ne mijenja, jer bi prema čl. 3. toč. 9. imovinska šteta, obična šteta, izmakla korist i neimovinska šteta trebale imati značenje određeno općim propisom obveznog prava, tj. ZOO-om, primjena predloženog propisa u praksi bi u naše pravo trebala donijeti određene promjene.

Smatramo nemogućim da šteta prouzročena povredom pravila tržišnog natjecanja u praksi zadrži isto značenje koje joj daje ZOO kao opći propis. Ako će pravila iz Prijedloga (kasnije zakona) primjenjivati u skladu s ciljevima Direktive i pravnom stečevinom Unije, suci trgovačkih sudova moraju se suočiti s problemom

12 Rasprave o tomu hoće li Direktiva uspjeti ostvariti postavljene ciljeve vidi kod: Peyer, Sebastian, Compensation and the Damage Ditrective, European Competition Journal, 2016., vol. 12., br. 1., str. 87-112., isti: The European Damages Directive fails to deliver, but can it be fixed?, https://competitionpolicy.wordpress.com/2015/03/03/the-european-damages-directivefails-to-deliver-but-can-it-be-fixed; Truli, op. cit., str. 299.-312.

13 U Prijedlogu prevladavaju odredbe postupovne i prekršajne prirode, odnosno odredbe kojima se uređuje pitanja otkrivanja dokaza i zaštite povjerljivih informacija te novčanih kazni za nepoštovanje istih, učinak odluka tijela nadležnih za zaštitu tržišnog natjecanja, zastoj postupka, tereta dokaza, sporazumnog rješavanja sporova, dakle, niz pitanja drugih pravnih područja (izvan odštetnog prava) te je bilo za očekivati da Prijedlog, odnosno budući zakon izazove puno veći interes šire znanstvene i stručne zajednice.

14 Kao jedno od najspornijih pitanje je uzročne veze između povrede prava tržišnog natjecanja i štete. Na uzročnoj se vezi "lomi" većina postupaka za naknadu štete u našem i poredbenom pravu. Iako se pravila o njoj razlikuju u nacionalnim sustavima, opće je prihvaćen stav da upravo uzročna veza predstavlja branu neograničenom širenju odgovornosti. Više o uzročnoj vezi kod povreda prava tržišnog natjecanja vidi infra, 2.3.

15 Preambula Direktive, recital 11. 
širenja odgovornosti za štetu izvan do sada u našem poretku prihvaćenih granica. Po samoj svojoj prirodi, radnje kojima se narušava tržišna utakmica nisu neposredno usmjerene na imovinska dobra niti prava osobnosti pojedinih pravnih i fizičkih osoba, već na samo stanje na tržištu. Stoga se uzročna veza kod ovih štetnih radnji mora vrlo elastično tumačiti, jer prema europskom pravu odgovornost štetnika treba dosezati do svih subjekata koji su zbog te radnje pretrpjeli neki gubitak (što nije slučaj kod drugih štetnih radnji). Naime, pravo na naknadu priznaje se svim fizičkim i pravnim osobama (potrošačima, poduzetnicima, tijelima javne vlasti) i to bez obzira jesu li sa štetnikom u ugovornom odnosu i je li tijelo nadležno za tržišno natjecanje prethodno već utvrdilo postojanje povrede pravila tržišnog natjecanja. ${ }^{16}$ Imovinska bi šteta, dakle, morala u određenoj mjeri izbjeći "kontroli” koju nad njom imaju opća pravila o odgovornosti, ponajprije ona o protupravnosti i uzročnoj vezi.

Direktiva nije propisala pravo na naknadu neimovinske štete prouzročene povredom prava tržišnog natjecanja, pa je naš predlagatelj zakona, predvidjevši isto u čl. 5. Prijedloga Zakona u zaštiti oštećenika otišao puno dalje. I dok se imovinski gubitci, bez obzira na njihovu "udaljenost" od štetne radnje, ipak mogu konkretizirati kao povećanje cijena i troškova, gubitak zarade i sl., kako se narušavanjem tržišne utakmice nanosi neimovinska šteta, za sada je, zbog izostanka sudske prakse, zaista teško reći.

\section{POVREDA PRAVA TRŽIŠNOG NATJECANJA KAO ŠTETNA RADNJA I OBJEKT TE POVREDE}

Povreda prava tržišnog natjecanja kao štetna radnja predstavlja radnju poduzetnika zabranjenu propisima o tržišnom natjecanju kojom je drugim subjektima nanesena šteta. Dvije su osnovne kategorije takvih radnji: zabranjeni sporazumi (čl. 101. UFEU, čl. 8. ZZTN) i zlouporabe vladajućeg položaja (čl. 102. UFEU, čl. 13. ZZTN). One se javljaju u različitim oblicima, od kartelskih sporazuma o cijenama i/ili podjeli tržišta, do različitih ponašanja poduzetnika koji koristeći svoj vladajući položaj na tržištu nanosi štetu drugim sudionicima istog (nametanjem nepravednih prodajnih ili kupovnih cijena, drugih nepravednih trgovinskih uvjeta, ograničavanjem proizvodnje, uvjetovanjem zaključenja ugovora nekim drugim, dodatnim obvezama nevezanim za predmet ugovora i sl.). Zbog povreda prava tržišnog natjecanja narušena je tržišna utakmica, a posljedice toga su nekonkurentne cijene proizvoda i usluga, smanjeni izbor i kvaliteta istih i sl. koje pogađaju potrošače kao krajnje korisnike. Za same sudionike (bilo samog tržišta na kojem je došlo do poremećaja ili njime povezanih tržišta na koja se štetne posljedice često prelijevaju) posljedice koje nastaju očituju se kao nemogućnost pristupa određenom tržištu, prisilno povlačenje s istog, nemogućnost ili otežanost ostvarivanja očekivane dobiti i poslovnog uspjeha i sl. ${ }^{17}$

16 Preambula Direktive, recitali 3. i 13.

Čl. 3. st. 1.: "Države članice osiguravaju da svaka fizička ili pravna osoba koja je pretrpjela štetu prouzročenu kršenjem prava tržišnog natjecanja može zahtijevati i dobiti potpunu naknadu za tu štetu."

17 Više o povredama pravila tržišnog natjecanja kao štetnim radnjama vidi: Vidi: Bukovac Puvača, 
Kada je za to nadležno tijelo donijelo odluku da je izvršena povreda prava tržišnog natjecanja, za potrebe postupka naknade štete to se, prema Prijedlogu smatra nepobitno dokazanim pravomoćnom odlukom Agencije za zaštitu tržišnog natjecanja $^{18}$ ili odlukom Visokog upravnog suda Republike Hrvatske (čl. 11. st. 1. Prijedloga), odnosno takve odluke tijela i sudova druge države članice obvezuju sud (čl. 11. st. 2. Prijedloga). U postupku se, dakle, ne može više raspravljati o protupravnosti djelovanja štetnika i kvalifikacija tijela nadležnih za zaštitu tržišnog natjecanja obvezujuća je za sud koji odlučuje o pravu na naknadu štete. Ovdje se radi o tzv. follow on action, postupcima za naknadu štete koji se vode nakon što je povreda utvrđena od za to nadležnog tijela, ${ }^{19}$ dok će u tzv. stand-alone action, samostalnim postupcima kojima ne prethode odluke regulatornih tijela, sudovi sami morati utvrditi protupravnost ponašanja poduzetnika, odnosno povredu prava tržišnog natjecanja. U državama u kojima se do sada već razvila praksa utuživanja ovih šteta, oštećenici se ipak ne upuštaju u samostalne postupke. ${ }^{20}$ Vjerujemo da će se i kod nas, ako se oštećenici potaknu na utuživanje ove vrste šteta, ponajviše pokretati postupci kojima će prethoditi odluka tijela nadležnog za zaštitu tržišnog natjecanja.

Budući da se štetne radnje mogu izvršiti na osobama, stvarima, činidbama i stanjima, a njima prouzročena šteta reflektira se na pravima i interesima pravnih subjekata, ${ }^{21}$ štete prouzročene povredama prava tržišnog natjecanja predstavljaju klasičan primjer šteta na stanjima. Da bi stanje moglo biti objektom štetne radnje, potrebno je da je ono zaštićeno pravom, što za konkurentnu strukturu tržišta nije sporno, jer je zaštićena europskim i nacionalnim propisima o tržišnom natjecanju. Objekt štetne radnje poduzetnika nije neposredno neko imovinsko ili neimovinsko dobro oštećenika, već samo tržište, odnosno utakmica na istom. Gubitci koje određeni subjekti trpe su posljedice poremećene strukture tržišta, a ne neposredno konkretnih zabranjenih radnji štetnika. Upravo je ta činjenica glavni izvor teškoća u primjeni nacionalnih pravila o odgovornosti na te gubitke. Oni prema europskom pravu moraju biti naknadivi iako to prema nacionalnim pravilima o odgovornosti za štetu u velikom dijelu ne bi bili.

\section{PRAVO NA POTPUNU NAKNADU ŠTETE PROUZROČENE POVREDOM PRAVA TRŽIŠNOG NATJECANJA}

\subsection{Gubitci koji se mogu kvalificirati kao šteta}

\subsubsection{O šteti u nacionalnim odštetnopravnim poredcima, PETL-u i DCFR-u}

Osnovno pitanje koje se nameće je koji će gubitci, nastali kao posljedica povrede tržišne utakmice biti naknadivi, odnosno priznati kao šteta. Odgovor na pitanje što je

Maja, Butorac, Vlatka, Izvanugovorna odgovornost za štetu prouzročenu povredom pravila tržišnog natjecanja, Hrvatska pravna revija, 12., 2008., str. 38.-39.

18 Dalje: Agencija.

19 Vidi opširnije ibid., str. 39. i tamo citiranu literaturu.

20 Vidi: Friederiszick, Rauber, loc. cit.

21 Klarić, Petar, Vedriš, Martin, Građansko pravo, Narodne novine, Zagreb, 2014., str. 588. 
šteta u određenom nacionalnom pravnom poretku ovisi o tomu kojim je sve pravima i interesima taj poredak pružio zaštitu i od kojih sve oblika gubitaka. Najopćenitije rečeno, šteta predstavlja pravno priznati gubitak, onaj za koji određeni pravni poredak oštećeniku priznaje pravo na njegovo popravljanje. Kao pojam, šteta izmiče mogućnosti jednostavnog i preciznog definiranja. Definiciju štete u nacionalnim poredcima uglavnom ne nalazimo u propisima, a i tamo gdje postoje te su definicije dovoljno općenite da sudska praksa pod njih podvodi različite gubitke. Stoga odgovor na pitanje što je šteta u određenom pravnom poretku može dati samo sudska praksa, jer šteta u njoj dobiva svoj konačan sadržaj. Iako je načelo potpune naknade štete široko prihvaćeno, svaki poredak daje mu svoj opseg, ovisan o primjeni drugih pravila o odgovornosti, posebno onih o protupravnosti i uzročnoj vezi kao općim pretpostavkama odgovornosti za štetu. Bez obzira na izostanak zakonskih definicija, i sudovi, i pravna teorija poredbenog prava šteti pristupaju slično, kao pojmu čije je značenje vrlo široko i njegovo precizno definiranje nije niti moguće niti poželjno. ${ }^{22}$

Stoga ne čudi da je vrlo sličan pristup pojmu štete prisutan i u dva teksta koji predstavljaju soft law harmonizaciju pravila odštetnog prava: ${ }^{23}$ Načelima europskog odštetnog prava ${ }^{24}$ i VI. knjizi Nacrta Zajedničkog referentnog okvira za europsko privatno pravo. ${ }^{25}$ PETL definiraju štetu kao materijalnu ili nematerijalnu povredu pravno zaštićenog interesa. ${ }^{26}$ Opseg zaštite određenog interesa ovisi o njegovoj prirodi: što je viša njegova vrijednost, preciznija definicija i veća očitost, opseg njegove zaštite je širi. Najširu zaštitu uživaju život, tjelesni i psihički integritet, ljudsko dostojanstvo i sloboda. Stvarna prava također uživaju široku zaštitu, dok je zaštita strogo ekonomskih prava i ugovornih odnosa nešto užeg opsega i kod njihove se povrede posebna pažnja posvećuje stupnju povezanosti između štetnika i oštećene osobe ili činjenici je li štetnik bio svjestan toga da će prouzročiti štetu. Na opseg zaštite može utjecati i priroda odgovornosti, pa interes može biti jače zaštićen od namjernih povreda. Kod određivanja opsega zaštite treba razmotriti i interese samog štetnika, njegovu slobodu djelovanja i vršenja prava i javni interes. ${ }^{27}$

I DCFR šteti pristupa kao pojmu vrlo širokog značenja. Govori o "pravno relevantnoj šteti” (engl. legally relevant damage), ${ }^{28}$ dakle o gubitcima koji su kao

22 Magnus, Ulrich, Comparative Report on the Law of Damages, u: Unification of Tort Law: Damages, Kluwer Law International, The Hague, London, Boston, 2001., str. 190.

23 O harmonizaciji odštetnog prava i navedenim tekstovima vidi: Petrić, Silvija, Usklađivanje europskog odštetnog prava, Zbornik radova Aktualnosti građanskog i trgovačkog zakonodavstva i pravne prakse, br. 7., Mostar, 2009., str. 121.-139., ista: Načela europskog odštetnog prava (PETL), Zbornik radova Aktualnosti građanskog i trgovačkog zakonodavstva i pravne prakse, br. 10., Mostar, 2012., str. 63.-77., ista: Nacrt Zajedničkog referentnog okvira za europsko privatno pravo, Zbornik Pravnog fakulteta Sveučilišta u Rijeci, vol. 30., br. 1., 2009., str. 473.513.

24 Principles of European Tort Law (PETL).

25 Draft Common Frame of Reference (DCFR).

26 PETL, Art. 2:101. Compensable damage: Damage requires material or immaterial harm to a legally protected interest (http://civil.udg.edu/php/biblioteca/items/283/PETL.pdf) (27.01.2017.)

27 Vidi PETL, Art. 2:102. Protected interests.

28 Chapter 2, Legallv relevant damage, sec. I, VI:-2:101, Meaning of legally relevant damage. 
takvi pravno bitni, odnosno priznati. Ekonomski ili neekonomski gubitak ili povreda pravno relevantan je ako tako određuje neko od pravila toga poglavlja, rezultat je povrede priznatog prava ili je rezultat povrede interesa koji zaslužuje pravnu zaštitu (2:101 (1)). U ova dva posljednja slučaja (kada nije samim DCFR-om određen kao pravno relevantan), gubitak ili povreda je pravno relevantna samo ako bi bilo pravično i razumno da postoji pravo na njeno popravljanje ili prevenciju. U razmatranju je li pravično da postoji pravo na popravak ili prevenciju treba obratiti pažnju na temelj odgovornosti, prirodu i blizinu štete ili prijeteće štete, razumna očekivanja osobe koja trpi ili će pretrpjeti štetu i pitanje općeg interesa (2:101 (2) i (3)). Ekonomski gubitak uključuje gubitak prihoda ili zarade, opterećenje i umanjenje vrijednosti imovine, dok neekonomski gubitak uključuje bol i patnju i pogoršanje kvalitete života (2:101 (4)).

\subsection{2. Šteta prema Direktivi}

Direktiva potvrđuje pravnu stečevinu Unije u pogledu prava na naknadu štete prouzročene povredama prava tržišnog natjecanja Unije, posebno one o procesnoj legitimaciji i definiciji štete iz sudske prakse Suda, "te se unaprijed ne određuje nikakav daljnji razvoj te pravne stečevine." ${ }^{29}$ Prema čl. 3. Direktive države moraju osigurati da svaka fizička ili pravna osoba koja je pretrpjela štetu prouzročenu povredom prava tržišnog natjecanja može zahtijevati i dobiti potpunu naknadu za tu štetu. ${ }^{30}$ Takva, potpuna naknada, mora staviti tu osobu u položaj u kojem bi bila da nije došlo do povrede prava tržišnog natjecanja i stoga uključuje pravo na naknadu za stvarni gubitak, izmaklu dobit $\mathrm{i}$ isplatu kamata. ${ }^{31}$ Potpuna naknada ne smije dovesti do prekomjerne naknade putem odštete radi kažnjavanja, višestruke ili druge vrste odštete. $^{32}$

Oštećenik dokazuje da mu je šteta nastala i u kojem iznosu. Za kartele se predmnijeva da je njima nastala šteta, a štetnik ima pravo dokazivati suprotno (čl. 17. st. 2. Direktive, čl. 5. st. 3. Prijedloga $\left.{ }^{33}\right) .{ }^{34}$ Za zloupotrebe vladajućeg položaja nije propisana takva predmnjeva.

Direktiva potpunom naknadom smatra onu koja uključuje stvarni gubitak (lat. damnum emergens), izmaklu dobit (lat. lucrum cessans) i kamate $\mathrm{i}$ to bez obzira

29 Preambula Direktive, recital 12. To su Presuda od 20. rujna 2001., Courage i Crehan, C-453/99, ECLI:EU:C:2001:465, t. 25. i 26., Presuda od 13. srpnja 2006., Manfredi i dr., C-295/04 do C-298/04, ECLI:EU:C:2006:461, t. 60. i 61., Presuda od 14. lipnja 2011., Pfleiderer, C360/09, ECLI:EU:C:2011:389, t. 28., Presuda od 6. studenog 2012., Otis $i$ dr., C-199/11, ECLI:EU:C:2012:684, t. 41. i 43. i Presuda od 6. lipnja 2013., Donau Chemie i dr., C -536/11, ECLI:EU:C:2013:366, t. 21.

30 Vidi: Courage i Crehan, C-453/99, t. 25. i 26.

31 Vidi: Manfredi i dr., C-295/04 do C-298/04, t. 60. i 61.

32 Vidi čl. 3. Direktive.

33 Čl. 5. st. 3. Prijedloga: Predmnijeva se da je zbog povrede prava tržišnog natjecanja počinjene u obliku kartela nastala šteta, osim ako štetnik na dokaže suprotno.

34 Čl. 5. st. 4. Prijedloga glasi: Za štetu nastalu povredom prava tržišnog natjecanja u obliku kartela smatra se da je prouzročena tim kartelom, osim ako se dokaže da taj kartel nije bio uzrok štete. Nije nam potpuno jasan odnos ova dva citirana stavka članka 5. Prijedloga, odnosno očekuje li se i koja je razlika kod njihove primjene u praksi. 
utvrđuju li se te kategorije nacionalnim pravom odvojeno ili u kombinaciji. Ističe se da su kamate bitna komponenta naknade $\mathrm{i}$ da bi se trebale plaćati od trenutka kada je nastala šteta do trenutka kada se naknada isplati, bez obzira na to kako su u nacionalnom pravu kvalificirane, kao kompenzacijske ili zatezne, odvojena kategorija ili sastavni dio stvarnog gubitka ili izmakle dobiti. Države članice moraju utvrditi pravila koja će se primjenjivati u tu svrhu. ${ }^{35}$

Što je viša vrijednost nekog interesa on ima širu zaštitu, što su autori PETL-a prepoznali kao načelo zajedničko europskim odštetnopravnim sustavima, vrijedi i za pravnu stečevinu o naknadi štete prouzročene povredom prava tržišnog natjecanja, ali ovdje su tržišna utakmica i ekonomski interesi koji se njome ostvaruju na prvom mjestu i njihova je zaštita primarna. Zaštita prava i interesa pojedinih subjekata kojima se pravo na naknadu jamči, samo je posljedica zaštite tržišta odnosno njegove konkurentne strukture, temeljnog dobra koje pravo tržišnog natjecanja štiti. Gubitci koji su u pravnoj stečevini kvalificirani kao šteta i na naknadu koje je pravnim subjektima priznato pravo, nisu to zbog svoje prirode, već isključivo zbog vrste štetne radnje čija su posljedica, odnosno objekta iste, tržišne utakmice.

Stoga, iako se kao prvi cilj Direktive navodi onaj da svatko tko pretrpi štetu učinkovito ostvari pravo na naknadu iste, teško se oteti dojmu da je osnovni cilj iste odvratiti potencijalne štetnike od zabranjenih ponašanja na tržištu. Tom našem dojmu pridonosi činjenica da niz prepreka oštećenika u ostvarivanju prava na naknadu Direktiva svojim rješenjima nije uspjela ni ukloniti niti ublažiti (npr. problem troškova postupka i pravo na kolektivnu pravnu zaštitu ${ }^{36}$ ), a nekim je pravilima o privatnopravnoj provedbi ugrozila učinkovitost javnopravne provedbe prava tržišnog natjecanja (npr. pravilima o otkrivanju dokaza ${ }^{37}$ ). Ako je zaista osnovni cilj da svaki oštećenik dobije naknadu za pretrpljenu štetu, za njegovo ostvarenje bi se trebao naći neki drugi, jednostavniji mehanizam naknađivanja od ovog na kojem se ustraje, uz svu svijest o teškoćama u njegovoj primjeni.

35 Preambula Direktive, recital 12.

36 Zbog svoje prirode, štete koje nastaju zbog povreda tržišnog natjecanja relativno jednostavno se s jednog oštećenika prebacuju na druge. Konkurenti štetnika i subjekti koji su s njima u neposrednoj vezi, gubitke koje pretrpe prebacuju na svoje klijente, oni na svoje i najbrojniji oštećenici su krajnji korisnici roba i usluga na koje se prevali najveći dio štete. Direktiva, međutim, pitanje mogućnosti zaštite tih najbrojnijih oštećenika (putem nekog o mehanizama kolektivne pravne zaštite) nije uspjela riješiti. Iako zajedno pretrpe najveći dio štete, pojedinačne štete koje trpe malih su iznosa i oni nisu motivirani pokretati skupe postupke i riskirati neuspjeh u njima.

37 Većinu postupaka utvrđivanja povreda prava tržišnog natjecanja u obliku kartela u posljednjih je nekoliko godina Komisija pokrenula na temelju dojava i suradnje uz nagodbe s pokajnicima. Otkrivanje dokaza, tj. dokumenata kojima se pokajnici izlažu građanskopravnoj odgovornosti, sigurno ne djeluje kao poticaj pokajnicima na suradnju s tijelima javnopravne provedbe prava tržišnog natjecanja. Stoga je praksa Komisije bila da odbijanje dostave dokaza iz pokajničkog programa (ne otkriva pokajnika da ga ne bi izložila građanskopravnoj odgovornosti). Međutim, Sud je u predmetima Pfleiderer, C360/09, t. 33. i Donau Chemie, C-536/11, t. 53. odbacio ideju da bi trebala postojati generalna zabrana otkrivanja tih dokaza, istaknuvši da zaštićeni interesi trebaju biti "izvagani" u svakom posebnom slučaju. Stoga su rješenja iz Direktive kompromis koji će biti komplicirano primjenjivati. 


\subsection{3. Šteta prema Prijedlogu}

Kako je uvodno navedeno, prema čl. 3. toč. 9. Prijedloga: Imovinska šteta, obična šteta, izmakla korist, neimovinska šteta: imaju značenje određeno općim propisom obveznog prava. Pojmovi imovinska i neimovinska šteta u tom se tekstu spominju još samo jednom, u odredbi čl. 5. st. 1. Prijedloga: Oštećenik ima pravo na potpunu naknadu imovinske štete i na popravljanje neimovinske štete prouzročene povredom prava tržišnog natjecanja, dok se pojam izmakle koristi spominje još samo kod obrane prenošenjem prekomjernih cijena (čl. 15. st. 1. Prijedloga). Uz formulaciju čl. 5. st. 1. Prijedloga (ako bude usvojena u ovom obliku), može se u primjeni postaviti pitanje jesu li, budući da se spominje samo naknada imovinske štete, isključeni drugi oblici njezina popravljanja, dok su, istovremeno, za neimovinsku štetu priznati svi oblici njezina popravljanja, a ne samo pravična novčana naknada? ${ }^{38}$

Prijedlog ne spominje pravo oštećenika na kamate. Vjerujemo da je razlog tomu činjenica što prema ZOO-u, kao i prema Direktivi, oštećenik ima pravo na potpunu naknadu. Sud dosuđuje naknadu u iznosu koji je potreban da se oštećenikova materijalna situacija dovede u stanje u kojem bi se nalazila da nije bilo štetne radnje ili propuštanja (čl. 1090. ZOO). Dužan je stoga uzeti u obzir i sve okolnosti koje su nastupile nakon prouzročenja štete. Visina naknade štete određuje se prema cijenama u vrijeme donošenja sudske odluke, osim ako bi zakon određivao što drugo (čl. 1089. st. 2. ZOO). Obveza naknade štete smatra se dospjelom od trenutka nastanka štete (čl. 1086. ZOO), a od pada u zakašnjenje $s$ isplatom naknade, štetnik oštećeniku duguje i zatezne kamate (čl. 29.-31. ZOO). Načelo potpune naknade štete kao opće načelo našeg odštetnog prava primjenjuje se uz određene iznimke, ${ }^{39}$ za koje smatramo da nema mjesta primjeni kod šteta prouzročenih povredom tržišnog natjecanja. Ono što bi moglo (zapravo, moralo) predstavljati novinu u našem pravu je to da se na imovinsku štetu (i stvarni gubitak i izmaklu korist) ne mogu primjenjivati neka pravila koja je, u općem odštetnopravnom režimu «drže» u određenim granicama.

Prema definiciji ZOO-a, obična je šteta umanjenje nečije imovine (čl. 1046. st. 1. ZOO), što bi u konkretnim slučajevima povreda prava tržišnog natjecanja predstavljala sva povećana materijalna davanja koja oštećenik ne bi imao da do povrede nije došlo. Običnu štetu bi, pojednostavljeno rečeno, predstavljala razlika u cijeni i drugim troškovima koje je oštećenik stvarno imao i one koje bi bio imao

38 ZOO popravljanje štete uređuje u svom Odsjeku 7. u kojem se čl. 1085.-1098. odnose na popravljanje imovinske, a čl. 1099.-1106. na popravljanje neimovinske štete. Imovinska se šteta osim novčanom naknadom može popravljati i povratom u prijašnje stanje, dok se neimovinska, osim pravičnom naknadom, može popravljati i neimovinskim oblicima popravljanja (objava presude, ispravka, povlačenjem izjave ili bilo čim drugim što može postići svrhu popravljanja). O popravljanju štete vidi više: Bukovac, Puvača, Maja, Slakoper, Zvonimir, Belanić, Loris, Obvezno pravo, Posebni dio II. Izvanugovorni odnosi, Novi informator, Zagreb, 2015., str. 228.-250.

39 Opći su izuzetci tzv. afekcijska cijena (čl. 1089. st. 4. ZOO), sniženje naknade (čl. 1091. ZOO), doprinos oštećenika (čl. 1092. st. 1. i 2. ZOO), dok u posebne spadaju štete nastale pri obavljanju općekorisne djelatnosti (čl. 1047. st. 3. i 4. ZOO) te slučajevi u kojima je propisan maksimalni ili minimalni iznos naknade. O načelu potpune naknade i izuzetcima vidi: ibid., str. 229.-235. 
na "zdravom" tržištu, na kojem povrede nije bilo. Izmakla korist je, prema definiciji ZOO-a, sprječavanje povećanja imovine (čl. 1046. st. 1. ZOO). Njeno detaljnije zakonsko određenje daje odredba čl. 1089. st. 3. ZOO-a, prema kojoj se pri ocjeni visine izmakle koristi uzima u obzir dobitak koji se mogao osnovano očekivati prema redovitom tijeku stvari ili prema posebnim okolnostima, a čije je ostvarenje spriječeno štetnikovom radnjom ili propuštanjem. Osnovanost očekivanja dobiti, pitanje je koje se procjenjuje s obzirom na sve okolnosti slučaja. I kod, uvjetno rečeno jednostavnih slučajeva, nije lako odrediti je li bilo osnovano očekivati tu dobit na strani oštećenika i ako je, koliko ona iznosi. Uvijek se radi o utvrđivanju vjerojatnosti da bi se nešto dogodilo i pitanje se u osnovi postavlja kao "što bi bilo da nije bilo štetne radnje". To je scenarij koji ostaje u domeni nagađanja, jer apsolutno provjerljivog odgovora nema.

\subsection{Obrana prenošenjem prekomjernih cijena i neizravni kupci kao oštećenici}

Povrede prava tržišnog natjecanja, odnosno njihove posljedice, negativno utječu ne samo na sudionike tržišnog natjecanja na tržištu na kojem su neposredno izvršene, već i na sudionike na s njime povezanim tržištima. Ova šteta pokazuje iznimnu sklonost da se "prelijeva", na susjedna tržišta, tržišta komplementarnih proizvoda i da zahvati različite razine lanca opskrbe. Stoga ju je, bez obzira na to o kojem se njenom obliku radi, teško izračunati.

Kod zabranjenih sporazuma, npr. kartelskih sporazuma o cijenama, izravni kupci štetnika (članova zabranjenih sporazuma), budući da su sa štetnicima u ugovornom odnosu, nemaju većih problema u dokazivanju uzročne veze između štetne radnje i štete koju su pretrpjeli. Neizravni kupci, oni koji kupuju proizvode i usluge ne od samih članova kartelskih sporazuma već od njihovih kupaca, u bitno su težem položaju. Njihova šteta ne nastaje neposredno, samom povredom pravila tržišnog natjecanja, već tako što kupci članova kartela štetu koju sami pretrpe ili njen dio prenesu na njih. Stoga se pri radu na Direktivi kao ključno postavilo pitanje treba li štetniku dopustiti prigovor da je njegov izravni kupac prenio štetu ili njen dio na svoje kupce te neizravnim kupcima priznati pravni interes i aktivnu legitimaciju. Naime, trebalo je spriječiti mogućnost da štetnik uopće ne odgovara ako uspije dokazati da je tužitelj štetu prenio dalje, ali i mogućnost da za istu štetu štetnik višestruko odgovara (i izravnom i neizravnom kupcu).

Direktiva je dopustila da štetnik ističe prigovor prenošenja stvarnog gubitka (razlike u cijeni koju je oštećenik stvarno platio i one koju bi bio platio da nije bilo povrede), odnosno da može dokazivati da je oštećenik dio ili sav svoj stvarni gubitak prenio na svoje kupce (pa to zapravo više nije njegova šteta i nema pravo na naknadu iste). Međutim, kako u takvim slučajevima prenošenja gubitaka može doći i do smanjene prodaje (zbog povećane cijene zbog prenošenja gubitka na kupce), oštećenik zadržava pravo tražiti naknadu za izmaklu dobit zbog te smanjene prodaje. ${ }^{40}$ U skladu s tim, čl. 15. st. 1. Prijedloga propisuje: Štetnik u postupku naknade štete

40 Preambula Direktive, recitali 39. i 40., čl. 12. i 13. Direktive. 
može kao obranu navesti činjenicu da je oštećenik u cijelosti ili djelomično prenio prekomjernu cijenu dalje niz lanac opskrbe te na taj način umanjio iznos obične štete koju je pretrpio. Takvo umanjenje ne dovodi u pitanje pravo na potpunu naknadu štete uključujući i pravo na izmaklu korist zbog potpunog ili djelomičnog prenošenja prekomjernih cijena.

Teret dokaza da je oštećenik prekomjernu cijenu prenio i u kojem opsegu, je na štetniku, koji u tu svrhu može tražiti otkrivanje dokaza od oštećenika i trećih osoba (čl. 13. Direktive, čl. 15. st. 2. Prijedloga). Omogućavanje korištenja navedenog prigovora (obrane) usko je povezano s pitanjem aktivne legitimacije neizravnih kupaca (onih na koje su izravni kupci štetnika prenijeli prekomjernu cijenu u cijelosti ili djelomično). $\mathrm{Na}$ oštećeniku neizravnom kupcu teret je dokaza da je na njega šteta prenesena i u kojoj mjeri. Smatra se da je dokazao da je prijenos izvršen ako dokaže da je štetnik izvršio povredu prava tržišnog natjecanja, da je ona dovela do prekomjerne cijene za izravnog kupca štetnika i da je on kupio robe i/ili usluge koje su bile predmetom povrede, iz njih su izvedene ili ih sadrže (čl. 14. Direktive, čl. 15. st. 3. Prijedloga). Postupci za naknadu štete s različitih razina lanca opskrbe ne smiju dovesti do višestruke odgovornosti štetnika niti do nepostojanja njegove odgovornosti. Naknada za običnu štetu na bilo kojoj razini lanca opskrbe ne smije premašiti štetu pretrpljenu od prekomjerne cijene na toj razini (čl. 12. st. 2. Direktive, čl. 16. st. 1. i 2. Prijedloga).

Ova se pravila odnose samo na konkretnu, "matematičku konstrukciju" pojedinog postupka za naknadu štete. Kao pravila o odgovornosti pojedinog štetnika za jednom štetnom radnjom ukupno prouzročenu štetu potpuno su neodrživa, odnosno neprimjenjiva. ${ }^{41}$

\section{3. Šteta prouzročena učinkom zaštitne cijene (engl. umbrella effects, umbrella pricing)}

Uz pitanje (ne)dopuštenosti obrane prenesenih prekomjernih cijena i aktivne legitimacije neizravnih kupaca, vrlo sporno pitanje naknade štete prouzročene povredom tržišnog natjecanja pitanje je proteže li se odgovornost štetnika i na štetu koju su pretrpjele osobe koje nisu njihovi kupci, već su kupci onih subjekata koji su, iako nisu sudjelovali u zabranjenom sporazumu podigli svoje cijene, koristeći učinke zabranjenog sporazuma.

Odgovor na to pitanje Sud je dao u slučaju Kone, ${ }^{42}$ povodom zahtjeva za

41 Budući da je moguće da se povodom iste štetne radnje vodi niz postupaka, pred različitim sudovima jedne i više država članica, koji će od njih odlučiti koliko iznosi ukupna šteta na određenoj razini lanca opskrbe? Sve što je matematički točno istovremeno nije i pravno provedivo, te je, bez obzira na navedena pravila jasno da su štetnici ipak izloženi mogućnosti da odgovaraju i za više iznose štete no što su je u određenoj razini opskrbe prouzročili.

42 Presuda od 5. lipnja 2014., Kone, C-557/12, ECLI:EU:C:2014:1317. Kone AG i druge sudionike zabranjenog sporazuma o podjeli tržišta dizala i pokretnih stepenica koji je primjenjivan više od dvadeset godina u nekoliko država članica, za naknadu štete u Austriji tužio je njihov klijent, koji je bio i klijent poduzetnika koji nije sudjelovao u tom zabranjenom sporazumu, ali je, prema mišljenju tužitelja, koristeći učinak zabranjenog sporazuma formirao cijene u višem iznosu nego bi to u normalnim tržišnim uvjetima bilo za očekivati. Prema austrijskom nacionalnom 
prethodnu odluku koji mu je uputio austrijski Vrhovni sud. Zbog primarnosti prava Unije austrijski Vrhovni sud pitao je, je li odbijanje prava na naknadu u ovakvom slučaju spojivo s načelom učinkovitosti. Sud je odlučio: Članak 101. UFEU- $a$ treba tumačiti na način da se protivi tumačenju i primjeni unutarnjeg prava države članice koje se sastoji u kategoričkom isključivanju, zbog razloga pravne prirode, građanske odgovornosti poduzetnika koji sudjeluju u zabranjenom sporazumu za štetu prouzročenu cijenama koje poduzetnik koji ne sudjeluje u tom sporazumu odredi, uzimajući u obzir djelovanje spomenutog sporazuma, u višem iznosu od onog koji bi primijenio da taj sporazum ne postoji. ${ }^{43}$

Budući da se radi o uzročnoj vezi, ključnom pitanju odgovornosti za štetu, ne samo u području tržišnog natjecanja, potrebno je istaknuti neke navode iz Mišljenja nezavisne odvjetnice ${ }^{44}$ u ovom slučaju. Prema austrijskom pravu, sudionicima zabranjenog sporazuma ne može se pripisati šteta od učinka zaštitne cijene, jer s jedne strane nedostaje potrebna odgovarajuća uzročna veza, a s druge zaštitni cilj pravila tržišnog natjecanja ne obuhvaća navodnu štetu. Nezavisna odvjetnica prvo detaljno obrazlaže zašto je odgovornost za učinak zaštitne cijene pitanje prava Unije, a ne nacionalnog prava ${ }^{45}$ a nakon toga iznosi i obrazlaže zahtjeve prava Unije za utvrđivanje uzročne veze. Ističe da bi bilo neprimjereno suziti krug potencijalnih ovlaštenika prava na naknadu na ugovorne partnere sudionika zabranjenih sporazuma ili njihove izravne ili neizravne kupce, jer time ne bi bila zajamčena potpuna učinkovitost zabrane takvih sporazuma. ${ }^{46}$ Poziva se na u sudskoj praksi postavljen zahtjev za dovoljno izravnom uzročnom vezom između štetnog ponašanja i navodne štete kod izvanugovorne odgovornosti institucija Unije prema čl. 340. st. 2. UFEU-a, koji je zbog koherentnosti potrebno prenijeti na sve druge slučajeve odgovornosti zbog povreda prava Unije. ${ }^{47}$

Što se podrazumijeva pod dovoljno izravnom uzročnom vezom? Kao prvo, izravna uzročna veza ne smije biti izjednačena s jedinom uzročnom vezom. To što je poduzetnik višu cijenu formirao na temelju slobodne poslovne odluke, ne znači da na to nisu utjecali sudionici zabranjenih sporazuma, dovoljno je da su oni barem doprinijeli formiranju zaštitne cijene. I kod prenošenja prekomjernih cijena na neizravne kupce poslovnu odluku donosi izravni kupac. Sadržajno kriterij dovoljne izravne uzročne veze mora osigurati da štetnik odgovara samo za one štete koje je mogao razumno predvidjeti i čija je naknada u skladu s postavljenim ciljevima povrijeđenog pravnog pravila ${ }^{48} \mathrm{U}$ tom smislu se za sudionike zabranjenih sporazuma odbija mogućnost da

pravu taj bi dio tužbenog zahtjeva trebalo odbiti jer se sudionicima zabranjenog sporazuma ne bi mogao pripisati učinak zaštitne cijene, pa bi štetnici odgovarali samo za prekomjernu cijenu dizala koja je tužitelj od njih kupio, ne i onih koje je kupio od poduzetnika koji nije sudionik njihova sporazuma.

43 Kone, C-557/12, t. 38.

44 Mišljenje nezavisne odvjetnice Juliane Kokott od 30. siječnja 2014., ECLI:EU:C:2014:45 (dalje. Mišljenje).

45 Vidi Mišljenje, t. 21.-30.

46 Mišljenje, t. 32.

47 Mišljenje, t. 34.

48 Mišljenje, t. 36.-40. 
bi im učinak zaštitne cijene bio nepredvidljiv, a neuvjerljivim ili neosnovanim svi prigovori koji negiraju da njegovo naknađivanje nije u cilju pravila kojima su takvi sporazumi zabranjeni. ${ }^{49}$

Neki autori iz analize slučaja Kone izvode zaključak da bi upravo privatnopravna provedba prava tržišnog natjecanja koja je posljednjih godina postala popularna mogla postati "izvrstan laboratorij za vrstu hibridne harmonizacije kroz legislativu (direktive) i sudsku praksu temeljenu na zajedničkim načelima koja se primjenjuju u državama članicama." ${ }^{50}$

\subsection{Određivanje visine iznosa štete}

Određivanje visine naknade štete ${ }^{51}$ jedno je od najsloženijih pitanja odštetnoga prava, bez obzira na to o kojoj se vrsti štete radi. Kod izgubljene dobiti kao oblika imovinske štete utvrđivanje da bi dobit bila ostvarena u domeni je vjerojatnosti. Kada postane (dovoljno) vjerojatno da bi oštećenik ostvario neku dobit, slijedi najteži dio, tj. izračun (procjena) koliko bi ona bila iznosila. Iako je pogrešno neki spor ocijeniti kao jednostavan, iz sudske prakse smo izdvojili dva slučaja koji bi, prema našoj procjeni, u odnosu na one zbog povreda prava tržišnog natjecanja, trebali biti puno jednostavniji, a sve radi ilustracije složenosti pojma i teškoća pri izračunu izmakle dobiti. U oba se slučaja radi o šteti nastaloj zbog raskida ugovora, a gdje su određene neke polazne vrijednosti, odnosno parametri koje treba uzeti u obzir (količina i cijena robe, količina i cijena sati rada... itd.).

U svojoj odluci Pž 3707/05 od 11. ožujka 2008. godine ${ }^{52}$ Visoki trgovački sud

49 Vidi Mišljenje, t. 41.-82.

50 Stuyck, Jules, Damages for Loss Caused by a Cartel: The Causal Link Comments on the Kone Judgment of the Court of Justice of the EU, European Rewiew of Private Law, 2015., vol. 23., br. 3., str. 459.-470.

51 Problem prevođenja nije tema ovoga rada, ali ipak smatramo potrebnim napomenuti da se u Prijedlogu i njegovom obrazloženju na nekim mjestima uspješno izbjeglo korištenje u našem pravu neuobičajenih termina. Naziv Poglavlja V., odnosno čl. 17. Direktive preveden je kao Kvantifikacija štete. U Prijedlogu se ipak koristi u našem odštetnom pravu uobičajeni, opisni izraz određivanje visine iznosa štete, što smatramo boljim rješenjem. Predlagatelj nije u tekst Prijedloga prenio za naše odštetno pravo nepoznat pojam "relativne odgovornosti" iz čl. 11. st. 5. i 6. Direktive, već govori o udjelu pojedinog solidarno odgovornog štetnika u ukupnoj šteti. U obrazloženju Prijedloga uz čl. 5. govori se o krivnji kao uvjetu odgovornosti, odnosno o dodatnim uvjetima za traženje naknade štete. Uvjet je u građanskom pravu buduća i neizvjesna okolnost, a kada zakonodavac propiše pod kojim se "uvjetima" odgovara, ti uvjeti postaju pretpostavke. Stoga krivnja nije uvjet već pretpostavka odgovornosti, ali budući da se odlučio ne tražiti krivnju kao pretpostavku odgovornosti, takvo određenje iste nije ušlo u tekst Prijedloga.

52 U ovom je slučaju tuženik-protutužitelj imao s trećim osobama zaključene ugovore o proizvodnji $\mathrm{i}$ isporuci akumulatora (tri ugovora s određenom količinom i određenom vrijednošću), koje su raskinule te treće osobe, inozemni kupci, jer tuženik nije izvršio svoju obvezu. Prema nalazu i mišljenju vještaka financijske struke u prvostupanjskom postupku je utvrđeno da izmakla dobit tuženika-protutužitelja iznosi 633.538,68 kn. Do tog iznosa je vještak došao uzimajući u obzir količinu akumulatora i prodajnu cijenu ugovorenu sa svakim od inozemnih kupaca, te uzimajući u obzir odbitak prema kalkulaciji troškova proizvodnje tako da izmakla dobit predstavlja razliku u cijeni, to jest očekivani profit koji je tuženiku izostao zbog raskida 
Republike Hrvatske (VTS) ističe: "Financijski vještak je visinu štete odnosno izmaklu dobit izračunao samo na temelju kalkulacije troškova. Za utvrđenje mogućnosti ostvarenja dobiti i visine dobiti potrebno je poznavanje tržišta, ponude i potražnje u odnosu na akumulatore u kritično vrijeme. Zbog toga je osnovana žaliteljeva primjedba o stručnosti vještaka. Tužitelj-protutuženik morao bi biti isključivo odgovoran što dobit nije ostvarena, a da je tuženik kod toga postupao savjesno, odnosno poduzeo sve što je mogao da bi ovu štetu umanjio odnosno otklonio. Naime, vještak nije obrazložio svoj nalaz i mišljenje, i na te okolnosti, nego je visinu štete utvrdio samo na temelju kalkulacije troškova." (...) "Pod izgubljenom dobiti podrazumijeva se samo ona dobit za koju je sigurno da bi je naručitelj, odnosno tuženik, dobio prema redovnom tijeku stvari ako bi izvođač, tj. tužitelj, ispunio svoju obvezu."

U odluci Pž 809/05 od 12. listopada 2005. godine ${ }^{53}$ VTS ističe: "Iz vještačkog nalaza je vidljivo da je vještak svoj nalaz i mišljenje utemeljio na podacima o smanjenju broja zaposlenika koji su obavljali poslove kontrole, te da je vještak primijenio tu kontrolu. Vještak navodi da bi se isti rezultat dobio i da se uzme količina kontrolirane nafte i utrošeni broj sati, te cijena iz ugovora (...) Vještak u svom dopunskom nalazu (...) osvrće se i na alternativno prikazanu izmaklu dobit (...), te ukazuje da izmakla dobit u ovom iznosu je rezultat prihoda koji nisu samo rezultat broj osoba koje obavljaju tu kontrolu, već broja sati kontrole i količine nafte koja se kontrolira. Iz ovakvoga nalaza vještaka proizlazi, da se način utvrđivanja izgubljene zarade može utvrđivati i drugom metodom - broj sati kontrole i količina nafte koja se kontrolira. Upravo iz razloga, što je vještak tijekom postupka vještačenja prezentirao različite visine iznose pretrpljene štete, te što je svoj nalaz bazirao na broju izvršitelja, ovaj sud nalazi da je potrebno u nastavku postupka izvršiti dopunsko vještačenje te izračunati izgubljenu zaradu na bazi broja sati obavljane kontrole, obzirom na količinu, a na što tuženik osnovano ukazuje u žalbi."

Ako se kod ugovorima definiranih iznosa koje oštećenik zbog štetnikove radnje nije ostvario javljaju teškoće pri njihovu kvalificiranju kao izmakle koristi, jasno je da su kod povreda tržišnog natjecanja te teškoće mnogo veće. Isto tako, pristup da se pod izgubljenom dobiti podrazumijeva samo ona dobit za koju je sigurno da bi je oštećenik ostvario doveo bi do toga da oštećenik gotovo nikad ne uspije s tužbenim zahtjevom, jer sigurnosti kod ove vrste gubitaka nema i ne može biti, samo veće ili manje vjerojatnosti.

Kao pomoć sudovima u složenom zadatku određivanja visine iznosa naknade na koju oštećenik ima pravo, Komisija je izradila Praktični vodič kvantifikacija štete u tužbama za naknadu štete temeljenima na povredi članka 101. ili 102. Ugovora o funkcioniranju Europske unije..$^{54}$ On je informativan i ne obvezuje nacionalne sudove. Sadrži niz informacija o samoj šteti koja nastaje povredom europskog prava tržišnog

navedena tri ugovora. Odluka dostupna na: http://www.sudacka-mreza.hr/sudska-praksa.aspx (27.01.2017.).

53 U ovom je slučaju bila sporna visina izmakle koristi koju je tužitelj pretrpio zbog jednostranog raskida dijela Ugovora o obavljanju poslova kvantitativne i kvalitativne kontrole sirove nafte. Odluka dostupna na: http://www.sudacka-mreza.hr/sudska-praksa.aspx (27.01.2017.).

$54 \mathrm{Na}$ hrvatskom jeziku dostupan na: http://ec.europa.eu/competition/antitrust/actionsdamages/ quantification_guide_hr.pdf (25.01.2017.). 
natjecanja te o brojnim metodama i tehnikama izračuna iste koje se mogu primijeniti u konkretnim slučajevima. Iako se odnosi na štetu prouzročenu povredom europskog prava tržišnog natjecanja, prikazane metode i tehnike mogu biti vrlo korisne i kod drugih povreda kod kojih se javlja potreba procjene što bi bilo da nije bilo određene štetne radnje.

Temeljno pitanje određivanja visine pretrpljene štete određivanje je što bi se dogodilo, kakvo bi stanje na tržištu bilo da nije bilo povrede pravila tržišnog natjecanja. Iz takvog se hipotetskog scenarija ("protučinjenični scenarij", engl. counterfactual scenario) predviđa kakav bi bio položaj oštećenika i uspoređuje se s onim kakav je on sada. Ta se analiza naziva "analizom no - zbog" (engl. but-for analysis) ${ }^{55}$ Ovisno o obliku štete za koju je tužitelj postavio zahtjev za naknadu, izabiru se ekonomske varijable koje će se uzeti u obzir (npr. cijena, količina prodaje, dobit, tržišni udio...). Sve te varijable ovise o nizu faktora na tržištu i njihovom međudjelovanju, složenoj interakciji sudionika tržišta i nemoguće je sa sigurnošću tvrditi kako bi se stanje na tržištu odvijalo da do povrede nije došlo. Stoga se hipotetski scenarij temelji na velikom broju pretpostavki, čemu u praksi jako puno doprinosi i nedostupnost potrebnih podataka. Nemoguće je odrediti precizan, onaj "pravi" iznos pretrpljene štete, već više ili manje preciznu procjenu istog. ${ }^{56}$

Zbog svijesti o velikim poteškoćama koje se kod izračuna šteta zbog povrede prava tržišnog natjecanja mogu javiti, Direktiva je ostavila mogućnost da se iznos štete procijeni prema slobodnoj ocjeni suda. Države članice moraju osigurati da standard dokazivanja potrebnog za izračunavanje štete ne čini pravo na naknadu štete praktički nemogućim ili pretjerano teškim, te stoga nacionalni sudovi moraju imati ovlast, u skladu s nacionalnim postupcima, procijeniti iznos štete ako je utvrđeno da ju je tužitelj pretrpio, ali je praktički nemoguće ili pretjerano teško točno je kvantificirati na temelju raspoloživih dokaza (čl. 17. st. 1. Direktive). To je propisano u čl. 17. st. 1. Prijedloga ${ }^{57}$ Države članice moraju osigurati da na zahtjev nacionalnog suda, nacionalno tijelo nadležno za tržišno natjecanje može pomoći sudu u određivanju iznosa naknade štete kada to tijelo takvu pomoć smatra primjerenom (čl. 17. st. 3. Direktive). Prijedlog je tu mogućnost propisao u čl. 17. st. 2.58, ali je izostavljena procjena primjerenosti takve pomoći nadležnog tijela za tržišno natjecanje. Hoće li se i u kom smjeru razvijati suradnja trgovačkih sudova i Agencije, po pitanju procjene iznosa štete, tek predstoji vidjeti.

Uz svu pomoć koji Praktični vodič može pružiti sucima, odnosno vještacima (teško da će se suci sami upuštati u izračune, bez obzira koliko im primjenjivih metoda i tehnika bilo objašnjeno), zadatak izračuna visine naknade na koju oštećenik ima pravo, nama se i dalje čini iznimno teškim. Stoga mogućnost da se na kraju iznos štete procijeni prema slobodnoj ocjeni suda, uz pomoć tijela nadležnog za tržišno

55 Vidi t. 11. i 12. Praktičnog vodiča, str. 9.-10.

56 Vidi t. 15.-17. Praktičnog vodiča, str. 10.

57 Čl. 17. st. 1. Prijedloga: Ako se utvrdi da stranci pripada pravo na naknadu štete, ali se na temelju raspoloživih dokaza visina iznosa pretrpljene štete ne može utvrditi ili bi se mogla utvrditi samo s nerazmjernim teškoćama, sud će procijeniti iznos štete prema slobodnoj ocjeni.

58 Čl. 17. st. 2. Prijedloga: Kod određivanja iznosa naknade štete sud može zatražiti stručnu pomoć tijela nadležnog za zaštitu tržišnog natjecanja. 
natjecanje, svakako treba pozdraviti, iako se tek treba vidjeti u kojim će se slučajevima ona koristiti, tj. kada će se smatrati da je praktički nemoguće ili pretjerano teško na temelju raspoloživih dokaza odrediti visinu te naknade.

\section{NEIMOVINSKA ŠTETA (POVREDE PRAVA OSOBNOSTI PROUZROČENE POVREDOM PRAVILA TRŽIŠNOG NATJECANJA)}

Člankom 5. Prijedloga propisano je da uz pravo na potpunu naknadu imovinske štete, oštećenik ima pravo i na popravljanje neimovinske štete prouzročene povredom prava tržišnog natjecanja. Ovim je naš predlagatelj zakona u zaštiti oštećenika išao dalje od propisanog Direktivom, budući da se u njoj ne spominje neimovinska šteta. To ne čudi, jer su po samoj svojoj prirodi štetne radnje o kojima je riječ ponajprije usmjerene na stanje na tržištu i posljedice istih su gubitci ekonomske prirode. Osim toga, po pitanju prava na popravljanje neimovinske štete pravnim osobama, nacionalni pravni sustavi jako se razlikuju i još uvijek prevladava restriktivan pristup, odnosno nepriznavanje pravnim osobama prava na naknadu te vrste štete.

Kao radnja usmjerena na stanje na tržištu, povreda prava tržišnog natjecanja neimovinska dobra pravnih subjekata moći će "zahvatiti" isključivo posredno. $\mathrm{Za}$ neimovinske štete koje nastanu posredno, tj. iz štetnih radnji čiji objekt nije neposredno neimovinsko dobro oštećenika, naš pravni poredak je do sada priznavao pravo na naknadu samo iznimno, kada je posebno propisana, kao u slučaju smrti ili teškog invaliditeta bliske osobe. ${ }^{59}$ Uskoro ćemo, dakle, u našem poretku imati još jedan takav slučaj priznavanja prava na naknadu za neimovinsku štetu, kada je ista prouzročena povredom prava tržišnog natjecanja.

Za neka prava osobnosti pravnih osoba ${ }^{60}$ može se tvrditi da se mogu povrijediti narušenom tržišnom utakmicom (npr. poduzetnik mora promijeniti dosadašnji način poslovanja što utječe na ugled i dobar glas koji je do sada imao ili potpuno prestati djelovati na tržištu čime je povrijeđena njegova sloboda privređivanja i sl.). Ipak, smatramo potrebnim naglasiti kako su to posredne povrede koje nastaju uz imovinsku štetu, ili kao posljedica iste, a nikada samostalno. Ako se za imovinsku štetu ističe da je određivanje visine naknade koju oštećenik treba dobiti zbog povrede pravila tržišnog natjecanja teško, ono je kod neimovinske štete višestruko teže. U poredbenim pravnim sustavima u kojima se u sudskoj praksi priznaje pravo na novčanu naknadu

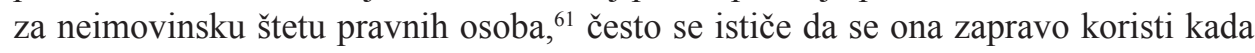

59 Čl. 1101. ZOO. Tako, npr. pravo na naknadu neimovinske štete nije priznato dječaku čiji je kućni ljubimac ubijen pred njegovim očima, jer radnja nije bila usmjerena na njegov život i zdravlje, iako je u postupku dokazano da je zbog iste imao zdravstvenih problema i trpio posljedice (ŽS u Varaždinu, Gž-1113/12-2., od 11. prosinca 2013., Portal IUS-INFO, http:// www.iusinfo.hr).

60 U čl. 19. ZOO-a navodi se primjerice prava osobnosti fizičkih i pravnih osoba, pri čemu pravne osobe imaju sva prava osobnosti kao i fizičke, osim onih koja su vezana uz biološku bit fizičkih osoba, "a osobito pravo na ugled i dobar glas, čast, ime, odnosno tvrtku, poslovnu tajnu, slobodu privređivanja i dr." (čl. 19. st. 3. ZOO).

61 O neimovinskoj šteti pravnih osoba u poredbenom pravu vidi: Klarić, Petar, Nematerijalna šteta pravne osobe, u: Odštetno pravo, Narodne novine, Zagreb, 2003., str. 325.-346. 
je teško ili nemoguće izračunati imovinsku štetu koju pravna osoba pretrpi. Budući da je Prijedlogom predviđeno izričito priznavanje prava na popravljanje neimovinske štete prouzročene povredom prava tržišnog natjecanja, pravična novčana naknada za neimovinsku štetu pravnih osoba, i u našem bi pravu mogla oštećenicima poslužiti u tu svrhu, "popravljanja" imovinske štete za koju je izvjesno da su je pretrpjeli, ali se ne može precizno odrediti, odnosno izračunati visina naknade. Hoće li u tom smjeru krenuti naša sudska praksa, teško je za predvidjeti, posebno stoga jer su odluke o pravičnoj naknadi zbog povrede prava osobnosti pravne osobe iznimno rijetke.

Fizičke osobe iz ovih štetnih radnji trpe ponajprije imovinsku štetu (u pravilu plaćaju više cijene). Stoga, kada se razmatra fizička osoba kao potencijalni oštećenik, subjekt kojem je povredom prava tržišnog natjecanja povrijeđeno neko pravo osobnosti, još nam je teže predvidjeti u kom bi smjeru sudska praksa mogla krenuti, no što je to kod oštećenika koji su pravne osobe.

\section{ZAKLJUČNE NAPOMENE}

Iako to prema izričitom tekstu predloženog zakona ne bi trebalo biti tako, pojam imovinske štete, u oba njezina oblika (stvarne štete i izmakle koristi), u našem bi pravu mogao doživjeti velike promjene. Iz izričito propisanih ciljeva Direktive, te sudske prakse europskih sudova koja je prethodila njenom donošenju, proizlazi da bi mnogi ekonomski gubitci, za koje je prema našoj dosadašnjoj sudskoj praksi bilo teško očekivati da osoba koja ih pretrpi dobije naknadu, trebali postati naknadivi, tj. dobiti kvalifikaciju štete. Odgovor na to hoće li se to i dogoditi ovisi o tomu hoće li nova pravila potaknuti oštećenike da štete prouzročene povredom prava tržišnog natjecanja zaista i utužuju. To bi trebalo vrijediti samo za gubitke koji su posljedica tih vrsta povreda, ali je teško zamisliti da to ne bi utjecalo i na "opći" pojam imovinske štete, odnosno štete nastale zbog drugih štetnih radnji.

Sva dosadašnja parcijalna ujednačavanja pravila o odgovornosti, izdvajanjem pojedinih područja koja se ujednačavaju bez obzira na nemogućnost usuglašavanja nekih temeljnih općih pravila, povlače za sobom i određene negativne posljedice. Radi osiguravanja jedinstvene primjene propisa i jednakosti na području Unije, otvara se mogućnost nejednakosti u nacionalnom poretku. Ne vidimo opravdanja da se oštećenici koji pretrpe istu vrstu gubitaka različito tretiraju, odnosno da oni koji pretrpe štetu zbog povrede prava tržišnog natjecanja budu u boljem položaju u odnosu na druge oštećenike. Smatramo da tumačenje pojma stvarne štete i izmakle dobiti kao posljedice povrede prava tržišnog natjecanja, treba biti jednako onom koje je posljedica neke druge štetne radnje. Što je šteta, više od bilo koje zakonske definicije govori doseg odgovornosti za istu, a taj je u pravu tržišnog natjecanja mnogo širi nego u drugim područjima građanskopravne odgovornosti u našem pravu (i nacionalnim pravima većine države članica).

Olakšavanje položaja oštećenika, kojem je Direktiva djelomično pridonijela vjerojatno će moći iskoristiti samo "veliki" igrači na tržištu, koji si mogu priuštiti troškove postupka i rizik koji taj postupak sa sobom nosi. Mali poduzetnici i pojedinci (potrošači) na koje se na kraju prelije većina štete vjerojatno će ipak ostati bez naknade. 
Ideja da će Direktiva uspjeti ostvariti jedan od ciljeva, da potpuna naknada bude dostupna svim oštećenima, teško će se ostvariti bez dodatnih zakonodavnih aktivnosti europskog i nacionalnih zakonodavaca. Bez kolektivne pravne zaštite i rješavanja pitanja troškova postupka, teško je očekivati njeno ostvarenje. Smatramo da bi se ideja obeštećenja svih oštećenih subjekata (posebno malih poduzetnika i potrošača) lakše ostvarila kroz neke druge mehanizme, izvan građanskopravnih postupaka za naknadu štete (npr. tijela za provedbu prava tržišnog natjecanja, budući da imaju pristup potrebnim informacijama i dokazima i mogućnost procjene okvirnog iznosa ukupne štete koje je određena takva povreda prouzročila, mogla bi obvezati štetnike na uplatu u neku vrstu fonda iz kojeg bi se oštećenicima naknađivali procijenjeni iznosi).

\section{LITERATURA}

Knjige i članci:

1. Bukovac Puvača, Maja, Butorac, Vlatka, Izvanugovorna odgovornost za štetu prouzročenu povredom pravila tržišnog natjecanja, Hrvatska pravna revija, 12, 2008., str. 32.-54.

2. Bukovac, Puvača, Maja, Slakoper, Zvonimir, Belanić, Loris, Obvezno pravo, Posebni dio II. Izvanugovorni odnosi, Novi informator, Zagreb, 2015.

3. Friederiszick, Hans, W., Rauber, Michael, A Fleet Without a Captain? Taking Stock of European Antitrust Litigation Post EU Directive, CPI Antitrust Cronicle, January, 2015 (1), www.competitionpolicyinternational.com

4. Klarić, Petar, Vedriš, Martin, Građansko pravo, Narodne novine, Zagreb, 2014.

5. Magnus, Ulrich, Comparative Report on the Law of Damages, u: Unification of Tort Law: Damages, Kluwer Law International, The Hague-London-Boston, 2001., str. 185.217.

6. Petrić, Silvija, Nacrt Zajedničkog referentnog okvira za europsko privatno pravo, Zbornik Pravnog fakulteta Sveučilišta u Rijeci, vol. 30., br. 1., 2009., str. 473.-513.

7. Petrić, Silvija, Načela europskog odštetnog prava (PETL), Zbornik radova Aktualnosti građanskog i trgovačkog zakonodavstva i pravne prakse, br. 10., Mostar, 2012., str. 63.77.

8. Petrić, Silvija, Usklađivanje europskog odštetnog prava, Zbornik radova Aktualnosti građanskog i trgovačkog zakonodavstva i pravne prakse, br. 7., Mostar, 2009., str. 121.139.

9. Peyer, Sebastian, Compensation and the Damage Ditrective, European Competition Journal, 2016, Vol. 12, no. 1., str. 87-112.

10. Peyer, Sebastian, The European Damages Directive fails to deliver, but can it be fixed?, https://competitionpolicy.wordpress.com/2015/03/03/the-european-damages-directivefails-to-deliver-but-can-it-be-fixed

11. Stuyck, Jules, Damages for Loss Caused by a Cartel: The Causal Link Comments on the Kone Judgment of the Court of Justice of the EU, European Rewiew of Private Law, 2015., Vol. 23, 3., str. 459.-470.

12. Truli, Emmanuela, Will Its provision Serve Its Goals? Directive 2014/104/EU on Certain Rules Governing Actions for Damages for Competition Law Infringements, Jouranl of European Competition Law \& Practice, 2016, Vol. 7., no 5, str. 299.-312. 
Pravni izvori:

1. Direktiva 2014/104/EU Europskog parlamenta i Vijeća od 26. studenoga 2014. godine o određenim pravilima kojima se uređuju postupci za naknadu štete prema nacionalnom pravu za kršenje odredaba prava tržišnog natjecanja država članica i Europske unije, Službeni list Europske unije, L 349/1, 5.12.2014.

2. Green Paper, damages actions for breach of the EC antitrust rules, COM (2005) 672 final, 19.12.2005.

3. White Paper on Damages Actions for Breach of the EC antitrust rules $\operatorname{COM}(2008) 165$, 2.4.2008.

4. Zakon o obveznim odnosima, Narodne novine, broj 35/05, 41/08, 125/11 i 78/15

5. Zakon o zaštiti tržišnog natjecanja, Narodne novine 79/09, 80/13

6. Principles of European Tort Law (PETL)

7. Draft Common Frame of Reference (DCFR)

8. Praktični vodič kvantifikacija štete u tužbama za naknadu štete temeljenima na povredi članka 101. ili 102. Ugovora o funkcioniranju Europske unije, http://ec.europa.eu/ competition/antitrust/actionsdamages/quantification_guide_hr.pdf

Sudska praksa:

Presuda od 20. rujna 2001., Courage i Crehan, C-453/99, ECLI:EU:C:2001:465

Presuda od 13. srpnja 2006., Manfredi i dr., C-295/04 do C-298/04, ECLI:EU:C:2006:461

Presuda od 14. lipnja 2011., Pfleiderer, C- 360/09, ECLI:EU:C:2011:389

Presuda od 6. studenog 2012., Otis i dr., C-199/11, ECLI:EU:C:2012:684

Presuda od 6. lipnja 2013., Donau Chemie i dr., C -536/11, ECLI:EU:C:2013:366

Presuda od 5. lipnja 2014., Kone, C-557/12, ECLI:EU:C:2014:1317

Mišljenje nezavisne odvjetnice Juliane Kokott od 30. siječnja 2014., ECLI:EU:C:2014:45

ŽS u Varaždinu, Gž-1113/12-2., od 11. prosinca 2013., Portal IUS-INFO, http://www.iusinfo.hr VTS, Pž 3707/05 od 11. ožujka 2008. godine

VTS, Pž 809/05 od 12. listopada 2005. godine 
Summary

\section{ECONOMIC LOSSES AS DAMAGE IN CROATIAN TORT LAW AFTER IMPLEMENTATION OF DIRECTIVE 2014/104/ EU}

Directive 2014/104/EU, which should facilitate the exercise of the right to compensation for damage caused by an infringement of competition law, has entered into force at the end of 2014. In this paper author draws attention to some issues of liability for damages recognized as disputable during the process of its adoption, but failed to regulate by European legislator. In more detail is analysed the notion of damage, for which Directive endeavour to ensure effective exercise the right to claim full compensation in the national courts of the EU Member States. Due to the nature of acts, which represent the infringements of competition law (anti-competitive agreements and abuse of dominance); application of adopted rules seems to be very complicated in practice. Particularly complex issues are passing-on defence, the indirect purchasers' right to claim, the recognition of the impact of protective prices ("umbrella effects") and quantification of damage. The paper presents the provisions of draft bill by which Directive should be transposed in Croatian legislation, related to the discussed issues.

Keywords: competition, compensation, material damage, non-pecuniary damage

Zusammenfassung

\section{WIRTSCHAFTLICHE VERLUSTE ALS SCHADEN IM KROATISCHEN DELIKTSRECHT NACH DER UMSETZUNG DER RICHTLINIE 2014/104/EU}

Die Richtlinie 2014/104/EU, welche die Ausübung des Anspruchs auf Schadenersatz wegen Verletzung des Wettbewerbsrechts erleichtern sollte, ist Ende 2014 in Kraft getreten. In diesem Artikel setzt sich die Autorin mit der Frage der Schadensersatzhaftung auseinander, die im Prozess seiner Annahme als strittig erkannt aber nicht vom europäischen Gesetzgeber reguliert wurde. Im Einzelnen wird der Begriff des Schadens analysiert, für den sich die Richtlinie bemüht, eine wirksame Ausübung des Anspruchs auf volle Entschädigung in den nationalen Gerichten der EUMitgliedstaaten zu gewährleisten. Aufgrund der Art der Schadenshandlungen, welche die Verletzung des Wettbewerbsrechts (wettbewerbswidrige Vereinbarungen und Missbrauch von Beherrschung) darstellen, scheint die Anwendung der verabschiedeten Regeln in der Praxis sehr kompliziert zu sein. Besonders komplex sind die Fragen der Verteidigung, des Anspruchs der indirekten Einkäufer, der Anerkennung der Auswirkungen von Schutzpreisen ("Umbrella-Effekte”) und der Quantifizierung von 
Schäden. Dieser Artikel enthält die Bestimmungen des Gesetzentwurfs, durch welche die Richtlinie in kroatischem Recht im Zusammenhang mit den diskutierten Fragen umgesetzt werden sollte.

Schlüsselwörter: Wettbewerb, Schadenersatz, Sachschaden, Vermögensschaden.

Riassunto

\section{LE PERDITE ECONOMICHE QUALI DANNI NEL DIRITTO RISARCITORIO CROATO DOPO L'ATTUAZIONE DELLA DIRETTIVA 2014/104/UE}

Alla fine dell'anno 2014 è stata varata la Direttiva 2014/104/UE, la quale dovrebbe facilitare la realizzazione del diritto al risarcimento del danno ai soggetti che subiscano un danno a causa della violazione del diritto della concorrenza. Il lavoro invita a prestare attenzione ad alcune delle questioni dibattute circa la responsabilità per i danni, le quali in occasione dell'emanazione della direttiva furono riconosciute come tali, benché il legislatore europeo non sia riuscito a dirimerle. Il lavoro tratta nel dettaglio del concetto di danno in sé, ovvero di quelle perdite a fronte delle quali la Direttiva si aspetta che i singoli stati membri nei relativi procedimenti per il risarcimento dei danni dinnanzi ai propri tribunali garantiscano un'efficace realizzazione del diritto al risarcimento degli stessi. In ragione della natura stessa dei fatti dannosi che inficiano la concorrenza (accordi vietati ed abuso di posizione dominante), si avverte che l'applicazione pratica delle soluzioni adottate potrebbe risultare assai complessa. In particolare si rilevano le questioni riguardanti l'obiezione del trasferimento transfrontaliero dei prezzi, il riconoscimento dell'interesse giuridico in capo ai compratori indiretti, il riconoscimento degli effetti del prezzo tutelato ed il calcolo dell'importo del risarcimento del danno che andrebbe riconosciuto in capo ai danneggiati. Nel lavoro si commentano le disposizioni della proposta di legge con la quale la Direttiva dovrebbe trovare attuazione nel nostro ordinamento, con particolare attenzione per quelle disposizioni che si riferiscono alle questioni oggetti del presente lavoro.

Parole chiave: concorrenza, ristoro del danno, danno patrimoniale, danno non patrimoniale. 